\title{
Effect of agro-ecological zone, season of birth and sex on pre-weaning performance of Nguni calves in Limpopo Province, South Africa
}

\author{
T. J. Mpofu ${ }^{1}$ (D) M. M Ginindza ${ }^{1} \cdot$ N. A. Siwendu ${ }^{1} \cdot$ K. A. Nephawe ${ }^{2} \cdot$ B. J. Mtileni ${ }^{2}$
}

Published online: 4 November 2016

(C) The Author(s) 2016. This article is published with open access at Springerlink.com

\begin{abstract}
The study was conducted to determine the effect of agro-ecological zone, season of birth and sex on Nguni calves' pre-weaning performance. Production indices such as birth weight (BW), weaning weight (WW), pre-weaning average daily gain $(\mathrm{P}-\mathrm{ADG})$ and pre-weaning gain $(\mathrm{P}-\mathrm{WG})$ were assessed in the different agro-ecological zones. Herd records on performance of 826 Nguni calves' from nine Nguni herds representing different agro-ecological zones: arid zone $(n=217)$; semi-arid zone $(n=296)$; dry sub-humid zone $(n=118)$ and humid zone $(n=195)$ were used for the analysis of pre-weaning calf performance. General linear model (GLM) procedure of SAS (2013) was used to analyse data, whereas mean separation was conducted using Tukey's HSD test. Agro-ecological zone had a great influence $(P<0.01)$ on performance levels arising from pasture conditions which were dependent on rain, temperature, topography and soil type. Fluctuations in WW, P-ADG and P-WG performance across agro-ecological zones depicted the sensitivity of Nguni calves' to postnatal stress. Calves' in humid zone had higher performance with $121.21 \mathrm{~kg}$ for $\mathrm{WW}, 96.83 \mathrm{~kg}$ for PWG and $0.477 \mathrm{~kg}$ /day for P-ADG. The lowest WW $(114.51 \mathrm{~kg}), \mathrm{P}-\mathrm{WG}(89.98 \mathrm{~kg})$ and P-ADG $(0.438 \mathrm{~kg} /$ day $)$ were observed in arid zone. Male calves were heavier at weaning (128.18 kg), P-ADG (0.503 kg/day) and total gain
\end{abstract}

T. J. Mpofu

takistar11@gmail.com

1 Department of Agricultural Economics and Animal Production, University of Limpopo, Private Bag X1106, Sovenga 0727 , South Africa

2 Department of Animal Science, Tshwane University of Technology, Private Bag X680, Pretoria 0001, South Africa
(103.03 kg); however, similar BW of $25 \mathrm{~kg}$ was observed for both male and female calves. Season had a significant $(P<0.05)$ effect on BW, P-ADG and P-WG. The P-ADG was $0.461 \mathrm{~kg} /$ day for calves born in summer and $0.449 \mathrm{~kg} /$ day for calves born in winter season. Calves born in summer gained $94.69 \mathrm{~kg}$ and calves born in winter gained $92.10 \mathrm{~kg}$. Summer calves gained $2.59 \mathrm{~kg}$ more than winter calves. Summer heifer calves performed poorly whilst summer male calves outperformed heifer calves in terms of WW, P-WG and P-ADG. Pre-weaned calves in humid zone outperformed all calves in other agro-ecological zones. It was concluded that acceptable levels of growth are achievable from Nguni cattle under the different agro-ecological zones of Limpopo province, South Africa.

Keywords Weaning weight $\cdot$ Pre-weaning average daily gain $\cdot$ Pre-weaning gain

\section{Introduction}

Growth of an animal is influenced by genetic and non-genetic factors (Bourdon 2000). The importance of growth rate in beef cattle production has received ample attention from various researchers (Arthur et al. 2001; Lawrence et al. 2002). The pre-weaning growth performance of a calf is one of the most important factors for beef productivity (Correa et al. 2006). Reduced growth performance is the major limiting factor amongst other factors of cattle production in the tropics (Jones and Hennessy 2000); however, challenges placed on production traits are mainly environmentally related (DuarteOrtuno et al. 1988; Howden et al. 1999). Mekonnen and Goshu (1996) reported that traits such as birth and weaning weight as well as growth and survival to weaning have important implications on herd productivity. 


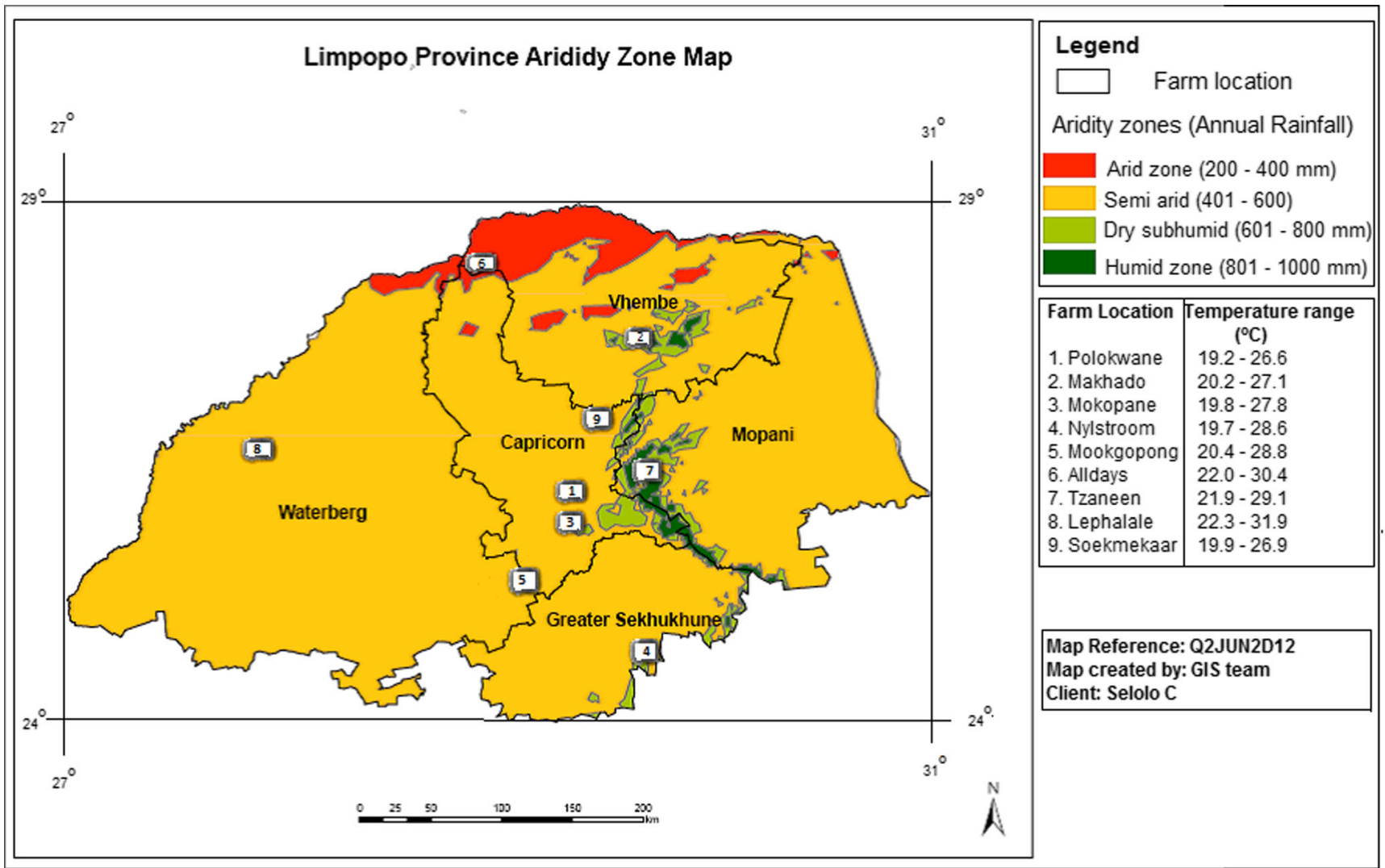

Fig. 1 Map representing the selected nine Nguni herds representing four agro-ecological zones of Limpopo Province, South Africa

Growth rate of livestock is influenced by several factors; these include production systems, breed, age, sex, nutritional level, hormonal status and environment (Owens et al. 1993; Moyo 1996). Production environments vary as a result of different management practices and constantly changing climatic conditions leading to variability in animal performance. An animal of good genetic value may perform poorly when the production environment is not favourable due to the negative interaction between the animal's genes and its environment (Botsime 2006).

Agro-ecological zone as described by rainfall, temperature, vegetation type, soil type and topography is a significant source of variation in pre-weaning production performance
(Bufenning et al. 1982; Dooley 1982; Ronchiotto 1993). Season of birth, the interaction between sex and season of birth and the interaction between agro-ecological region and season of birth are important sources of variation in growth of beef cattle (Botsime 2006). Keeping animals that are in harmony with the environment in which they are maintained result in the maximum utilisation of natural resources. Birth weight (BW), weaning weight (WW), pre-weaning average daily gain (P-ADG) and pre-weaning gain (P-WG) are several measures of calves' pre-weaning production performance. There is currently a paucity of information on the Nguni calves preweaning production performance in different agro-ecological
Table 1 Agro-ecological zones and their features in Limpopo Province, South Africa

\begin{tabular}{llll}
\hline Eco-zone & Location & Veld type & Prevailing grass species \\
\hline Arid & Alldays & Sweet & Cenchrus ciliaris, Panicum maximum \\
& Lephalale & Mixed & Aristida tranvaalenesis, Panicum maximum \\
& Polokwaane & Mixed & Eragristis curvula, E. capensis \\
Semi-arid & Mokopane & Sourveld & Eragristis curvula, E. capensis \\
& Nylstroom & Sourveld & Panicum maximum, Themeda triandra \\
& Mookgopong & Sourveld & Panicum maximum, Themeda triandra \\
& Soekmekaar & Mixed & Eragristis curvula, Themeda trianda \\
Dry sub-humid & Makhado & Sweet & Panicum maximum, Eragrostis Frichophora \\
Humid & Tzaneen & Sourveld & Cymbopogon caesius, Themeda trianda \\
\hline
\end{tabular}


Table 2 Classification of seasons according to months of birth

\begin{tabular}{lll}
\hline Season & Sate of vegetation & Month of birth \\
\hline Summer & Green pastures & November \\
& & December \\
& Dry pastures & January \\
Winter & & May \\
& & June \\
& July \\
\hline
\end{tabular}

zones. This research was therefore conducted to determine the effect of agro-ecological zone, season of birth and sex on Nguni calves pre-weaning performance in Limpopo province.

\section{Materials and methods}

Secondary herd records on 826 Nguni calves from 2008 to 2013 obtained from nine Nguni herds representing four different agro-ecological zones were used in this study (Fig. 1). The agro-ecological zones were as follows: arid zone $(n=217)$; semi-arid zone $(n=296)$; dry sub-humid zone $(n=118)$ and humid zone $(n=195)$. The selected agro-ecological zones vary in rainfall distribution, temperature, major topographic features, vegetation type and farming systems (Table 1).

All selected herds were kept under extensive grazing system. Herds comprise of one bull and thirty (30) females were made for breeding purposes. Cows were exposed to bulls for limited breeding period of 90 days in two breeding seasons (Table 2). All calves were weaned simultaneously when the last calf reached 205 days of age. No supplementary feeding or licks was supplied.

P-ADG, P-WG and corrected weaning weight were determined using the following equations:

$\mathrm{P}-\mathrm{ADG}=\frac{\text { Weight gain }(\mathrm{kg})}{\text { Days in trial }(\text { days })}$

Corrected Weaning weight $=\mathrm{BW}+a\left(\frac{\text { Actual WW-BW }}{\text { Age in days at weaning }}\right) \times 100$

(Szabo et al. 2012)

where $a=$ constant (205 days)

BW birth weight

WW weaning weight

$\mathrm{P}-\mathrm{WG}=$ Corrected weaning weight $(\mathrm{kg})-\mathrm{BW}(\mathrm{kg})$
Performance data was analysed using the PROC GLM procedure of SAS (2013). Factors fitted in the model included agro-ecological zone, calving season, sex of calf, agroecological zone $\times$ season interactions and agro-ecological zone $\times$ sex of calf interactions. Tukey's honestly significant difference (HSD) test was used to test for significant differences between treatment means $(P<0.05)$. The following model was used:

$\mathrm{Y}_{\mathrm{ikl}}=\mu+\mathrm{H}_{\mathrm{j}}+\mathrm{S}_{\mathrm{k}}+\mathrm{T}_{\mathrm{l}}+\mathrm{HS}_{\mathrm{jk}}+\mathrm{HT}_{\mathrm{jl}}+\mathrm{HST}_{\mathrm{ikl}}+\mathrm{e}_{\mathrm{ijk}}$

where

$\mathrm{Y}_{\mathrm{ikl}} \quad$ Observations on BW, WW, Pre-weaning ADG and P-WG

$\mu \quad$ Underlying constant common to all observations

$\mathrm{H}_{\mathrm{j}} \quad$ Fixed effect of agro-ecological zone

$\mathrm{S}_{\mathrm{k}} \quad$ Fixed effect of season of birth

$\mathrm{T}_{1} \quad$ Fixed effect of sex of calves

$\mathrm{HS}_{\mathrm{jk}} \quad$ Agro-ecological zone $\times$ season interactions

$\mathrm{HT}_{\mathrm{jl}} \quad$ Agro-ecological zone $\times$ sex of calf interactions

$\mathrm{HST}_{\mathrm{ikl}} \quad$ Agro-ecological zone $\times$ season $\times$ sex interactions

$\mathrm{e}_{\mathrm{jkl}} \quad$ Random residual/error

\section{Results}

Sex of calves was a significant $(P<0.05)$ source of variation for WW and P-WG; however, BW and P-ADG were not affected $(P>0.05)$ by sex of calves (Table 3$)$. Male calves recorded higher WW (128.18 kg), P-ADG (0.503 kg/day) and P-WG $(103.03 \mathrm{~kg})$ than heifer calves.

The interaction between agro-ecological zone and sex of calves is presented in Table 4. Male calves in arid zone were lighter $(123.42 \mathrm{~kg})$ at weaning whilst male calves in semi-arid were heavier $(128.78 \mathrm{~kg})$ than all male calves throughout agroecological zones. Female calves in humid zone were lighter at birth $(23.42 \mathrm{~kg})$ whilst female calves from dry sub-humid zone were heavier $(24.58 \mathrm{~kg})$ than all female calves throughout agroecological zones. However, female calves in arid zone performed poorly $(\mathrm{WW}=105.60 \mathrm{~kg}, \mathrm{P}-\mathrm{ADG}=0.394 \mathrm{~kg} /$ day, $\mathrm{P}$ $\mathrm{WG}=80.69 \mathrm{~kg}$ ) whilst male calves in humid zone performed better $(\mathrm{WW}=131.66 \mathrm{~kg}, \mathrm{P}-\mathrm{ADG}=0.514 \mathrm{~kg} / \mathrm{day}, \mathrm{P}-\mathrm{WG}=$ $106.34 \mathrm{~kg}$ ) than all calves throughout the agro-ecological
Table 3 Effect of sex of calves on pre-weaning calf performance $(\mathrm{kg})$ of Nguni cattle in Limpopo province, South Africa

\begin{tabular}{lllll}
\hline Source & Birth weight $(\mathrm{kg})$ & Weaning weight $(\mathrm{kg})$ & P-ADG $(\mathrm{kg} / \mathrm{day})$ & P-WG $(\mathrm{kg})$ \\
\hline Female & $24.89^{\mathrm{a}} \pm 0.2025$ & $108.62^{\mathrm{b}} \pm 0.8994$ & $0.413^{\mathrm{b}} \pm 0.1283$ & $83.73^{\mathrm{b}} \pm 0.9207$ \\
Male & $25.15^{\mathrm{a}} \pm 0.2042$ & $128.18^{\mathrm{a}} \pm 0.9069$ & $0.503^{\mathrm{a}} \pm 0.1294$ & $103.03^{\mathrm{a}} \pm 0.9283$ \\
\hline
\end{tabular}

a, b Column means with different superscripts differ significantly $(P<0.05)$ 
Table 4 Agro-ecological zone and sex of calves' interaction effects on pre-weaning calf performance $(\mathrm{kg})$ of Nguni cattle in Limpopo province, South Africa

\begin{tabular}{llllll}
\hline Source & $N$ & BW & WW & P-ADG & P-WG \\
\hline Arid $\times$ female & 114 & $24.91^{\mathrm{bcd}} \pm 0.36$ & $105.60^{\mathrm{c}} \pm 1.60$ & $0.394^{\mathrm{d}} \pm 0.23$ & $80.69^{\mathrm{b}} \pm 1.64$ \\
Arid $\times$ male & 103 & $24.15^{\mathrm{cd}} \pm 0.39$ & $123.42^{\mathrm{b}} \pm 1.71$ & $0.487^{\mathrm{d}} \pm 0.24$ & $99.26^{\mathrm{a}} \pm 1.75$ \\
Semi-arid $\times$ female & 147 & $25.08^{\mathrm{bc}} \pm 0.32$ & $111.18^{\mathrm{c}} \pm 1.43$ & $0.424^{\mathrm{c}} \pm 0.20$ & $86.10^{\mathrm{b}} \pm 1.47$ \\
Semi-arid $\times$ male & 149 & $26.54^{\mathrm{a}} \pm 0.32$ & $128.78^{\mathrm{ab}} \pm 1.44$ & $0.502^{\mathrm{bc}} \pm 0.21$ & $102.24^{\mathrm{a}} \pm 1.47$ \\
Dry sub-humid $\times$ female & 57 & $24.58^{\mathrm{bcd}} \pm 0.52$ & $128.86^{\mathrm{ab}} \pm 2.31$ & $0.394^{\mathrm{ab}} \pm 0.33$ & $104.28^{\mathrm{a}} \pm 2.37$ \\
Dry sub-humid $\times$ male & 61 & $26.15^{\mathrm{ab}} \pm 0.49$ & $106.96^{\mathrm{c}} \pm 2.18$ & $0.509^{\mathrm{abc}} \pm 0.31$ & $80.81^{\mathrm{b}} \pm 2.23$ \\
Humid $\times$ female & 88 & $23.42^{\mathrm{d}} \pm 0.43$ & $110.75^{\mathrm{c}} \pm 1.90$ & $0.430^{\mathrm{a}} \pm 0.27$ & $87.33^{\mathrm{b}} \pm 1.94$ \\
Humid $\times$ male & 107 & $25.32^{\mathrm{abc}} \pm 0.38$ & $131.66^{\mathrm{a}} \pm 1.68$ & $0.514^{\mathrm{a}} \pm 0.24$ & $106.34^{\mathrm{a}} \pm 1.72$ \\
\hline
\end{tabular}

a, b, c, d Values in the same column with different superscripts differ significantly $(P<0.05)$

$B W$ birth weight, $W W$ weaning weight, $P-A D G$ pre-weaning average daily gain, $P-W G$ pre-weaning gain zones. This also shows that whatever the agro-ecological zone, male calves yielded better performance than their female contemporaries on the variables studied.

Agro-ecological zone was a significant $(P<0.05)$ source of variation for weights at birth and weaning, $\mathrm{P}-\mathrm{ADG}$ and $\mathrm{P}-\mathrm{WG}$ of Nguni calves (Table 5). The birth weight was highest in semi-arid zone $(25.81 \mathrm{~kg})$. Pre-weaning weights of Nguni calves in the semi-arid and humid zones were higher $(P<0.05)$ than those of calves in the arid zone. However, calves of the arid zone and dry sub-humid zones had similar $(P>0.05)$ WW. Similarly, calves in semi-arid, dry semihumid and humid zones had similar $(P>0.05) \mathrm{WW}$. The PADG of calves from all agro-eco zones differed significantly from each other. The WW was highest in humid zone $(121.21 \mathrm{~kg})$ and lowest in arid zone $(114.51 \mathrm{~kg})$. Calves in humid zone gained more weight than calves in all other agroecological zones. The P-ADG was highest in humid zone $(0.477 \mathrm{~kg} /$ day $)$ and lowest in arid zone $(0.438 \mathrm{~kg} /$ day $)$.

Season effect on pre-weaning calves performance of Nguni cattle in Limpopo Province is presented in Table 6. Season had a significant effect on BW, P-ADG and P-WG. Season of birth had no effect $(P>0.05)$ on WW. Summer calving season yields higher WW, P-ADG $(0.461 \mathrm{~kg} /$ day $)$ and $\mathrm{P}-\mathrm{WG}$ $(94.69 \mathrm{~kg})$ than winter calves. Summer calves gained $2.57 \mathrm{~kg}$ more than winter calves.

Table 7 shows the effect of agro-ecological zone and season of birth on pre-weaning traits of Nguni calves. In arid and semi-arid areas, the performances of animals born in the summer are better than those of animals born in winter. In sub-humid and humid areas, the performances of animals born in the winter are better than those of animals born in summer.

The interaction between season of birth and sex of calves is presented in Table 8. There was no significant $(P>0.05)$ effect of season and sex of calves' interaction on BW; however, effects $(P<0.05)$ were observed in WW and P-WG. Male summer calves and winter female calves performed better $(P<0.05)$ than male winter calves and female summer calves in terms of WW and P-WG.

\section{Discussion}

Agro-ecological zone as described by rainfall, temperature, vegetation type, soil type and topography is a significant source of variation and explains 6.8 and $3.4 \%$ of the variation in pre-weaning and weaning weight, respectively (Bufenning et al. 1982; Dooley 1982; Ronchiotto 1993). Fluctuations in WW, P-ADG and P-WG performance across the agroecological zones depict the sensitivity of calves to postnatal stress and can be attributed to nutritional differences between the agro-ecological zones. The findings of this study that wide variation in agro-ecological zone influences any performance traits under study agree with several reports, BW (Burfenning et al. 1982), WW (Dooley et al. 1982; Leighton et al. 1982), PWG (Treden et al. 1982). These findings are in agreement with the several reports (Wollny 1995; Boitsime 2006; Zindove
Table 5 Pre-weaning calf performance $(\mathrm{kg})$ of Nguni cattle in different agro-ecological zones of Limpopo Province, South Africa

\begin{tabular}{llllll}
\hline Source & $N$ & BW & WW & P-ADG & P-WG \\
\hline Arid & 217 & $24.53^{\mathrm{b}} \pm 0.26$ & $114.51^{\mathrm{b}} \pm 1.17$ & $0.438^{\mathrm{d}} \pm 0.17$ & $89.98^{\mathrm{b}} \pm 1.20$ \\
Semi-arid & 296 & $25.81^{\mathrm{a}} \pm 0.23$ & $119.98^{\mathrm{a}} \pm 1.01$ & $0.464^{\mathrm{c}} \pm 0.15$ & $94.17^{\mathrm{a}} \pm 1.04$ \\
Dry sub-humid & 118 & $24.36^{\mathrm{b}} \pm 0.36$ & $117.91^{\mathrm{ab}} \pm 1.59$ & $0.450^{\mathrm{b}} \pm 0.23$ & $92.55^{\mathrm{ab}} \pm 1.62$ \\
Humid & 195 & $25.36^{\mathrm{ab}} \pm 0.29$ & $121.21^{\mathrm{a}} \pm 1.27$ & $0.477^{\mathrm{a}} \pm 0.18$ & $96.83^{\mathrm{a}} \pm 1.30$ \\
Means & 826 & $25.02 \pm 0.29$ & $118.40 \pm 1.26$ & $0.458 \pm 0.18$ & $93.38 \pm 1.29$ \\
\hline
\end{tabular}

a, b , c , Column means with different superscripts differ significantly $(P<0.05)$

$B W$ birth weight, $W W$ weaning weight, $P-A D G$ pre-weaning average daily gain, $P-W G$ pre-weaning gain 
Table 6 Effect of season of birth on pre-weaning calf performance (kg) of Nguni cattle in Limpopo province, South Africa

\begin{tabular}{lllll}
\hline Season & Birth weight $(\mathrm{kg})$ & Weaning weight $(\mathrm{kg})$ & P-ADG $(\mathrm{kg} /$ day $)$ & P-WG $(\mathrm{kg})$ \\
\hline Summer & $24.71^{\mathrm{a}} \pm 0.1838$ & $119.37^{\mathrm{a}} \pm 0.8163$ & $0.461^{\mathrm{a}} \pm 0.1165$ & $94.67^{\mathrm{a}} \pm 0.8356$ \\
Winter & $25.33^{\mathrm{b}} \pm 0.2212$ & $117.43^{\mathrm{a}} \pm 0.9824$ & $0.449^{\mathrm{b}} \pm 0.1402$ & $92.10^{\mathrm{b}} \pm 1.0055$ \\
\hline
\end{tabular}

${ }^{\mathrm{a}, \mathrm{b}}$ Column means with different superscripts differ significantly $(P<0.05)$
Table 7 Agro-ecological zone and season of birth interaction effects on pre-weaning calf performance $(\mathrm{kg})$ of Nguni cattle in Limpopo province, South Africa

\begin{tabular}{llllll}
\hline Source & $N$ & BW & WW & P-ADG & P-WG \\
\hline Arid $\times$ summer & 125 & $24.10^{\mathrm{b}} \pm 0.34$ & $116.14^{\mathrm{bc}} \pm 1.52$ & $0.449^{\mathrm{c}} \pm 0.22$ & $92.04^{\mathrm{abc}} \pm 1.56$ \\
Arid $\times$ winter & 92 & $24.96^{\mathrm{ab}} \pm 0.40$ & $112.87^{\mathrm{c}} \pm 1.78$ & $0.424^{\mathrm{c}} \pm 0.25$ & $87.91^{\mathrm{c}} \pm 1.82$ \\
Semi-arid $\times$ summer & 182 & $25.38^{\mathrm{ab}} \pm 0.28$ & $123.18^{\mathrm{a}} \pm 1.26$ & $0.478^{\mathrm{b}} \pm 0.18$ & $97.80^{\mathrm{a}} \pm 1.29$ \\
Semi-arid $\times$ winter & 114 & $26.24^{\mathrm{a}} \pm 0.36$ & $116.78^{\mathrm{bc}} \pm 1.59$ & $0.441^{\mathrm{b}} \pm 0.23$ & $90.53^{\mathrm{bc}} \pm 1.63$ \\
Dry sub-humid $\times$ summer & 66 & $25.22^{\mathrm{ab}} \pm 0.47$ & $117.68^{\mathrm{abc}} \pm 2.10$ & $0.455^{\mathrm{ab}} \pm 0.30$ & $92.47^{\mathrm{abc}} \pm 2.14$ \\
Dry sub-humid $\times$ winter & 52 & $25.51^{\mathrm{ab}} \pm 0.54$ & $118.14^{\mathrm{abc}} \pm 2.38$ & $0.443^{\mathrm{ab}} \pm 0.34$ & $92.64^{\mathrm{abc}} \pm 2.44$ \\
Humid $\times$ summer & 122 & $24.132^{\mathrm{b}} \pm 0.35$ & $120.50^{\mathrm{ab}} \pm 1.54$ & $0.472^{\mathrm{a}} \pm 0.22$ & $96.37^{\mathrm{ab}} \pm 1.58$ \\
Humid $\times$ Winter & 73 & $24.61^{\mathrm{ab}} \pm 0.45$ & $121.91^{\mathrm{ab}} \pm 2.01$ & $0.484^{\mathrm{a}} \pm 0.29$ & $97.30^{\mathrm{ab}} \pm 2.06$ \\
\hline
\end{tabular}

a, b, c, d Values in the same column with different superscripts differ significantly $(P<0.05)$

$B W$ birth weight, $W W$ weaning weight, $P-A D G$ pre-weaning average daily gain, $P-W G$ pre-weaning gain
2014; de Waal 1990) who deduced that economically important traits in livestock are influenced by variation in the production environment.

The finding that calves in arid zone are lighter in WW, PADG and P-WG could be a direct result of poor nutrition, rainfall pattern, veld type, mineral status of the soil and heat stress. However, these areas are characterised by fluctuations in forage quality and quantity resulting in continuous cyclic livestock weight losses and gains which is confirmatory to several reports (DeNise and Ray 1987; Boitsime 2006). The arid and semi-arid zones are subjected to frequent droughts and low rainfall as compared to sub-humid and humid zones. This is in line with arguments put forward by Maciel et al. (2013) that Nguni cattle kept under different environments will perform differently.

Low WW, P-WG and P-ADG in arid zone may also be attributed by exposure of nursing dams to prolonged nutritional stress leading to reduced milk production hence nutrient deprivation in the calves. Variations in WW, PWG and WW can be a result to differences in milk production between dams which is directly influenced by agro-ecological zone factors such as rainfall, temperature and type of vegetation. This also agrees with several reports (Letholu 1983; Dionisio 1989; Bothma 1993; Erat and Buchanan 2005) that 50 to $70 \%$ of WW, P-WG and $\mathrm{P}-\mathrm{ADG}$ variation is caused by agro-ecological factors. Arid and semi-arid zone summer calves yielded more weight because they were calved in the season where most rainfall is received (Schulze 1997) which in turn leads to higher milk production by their dams. On contrary, humid and sub-humid zones receive enough rainfall throughout, but their soils have low levels of phosphorus (Hunters and Buck 1992) which may reduce feed intake, reduced weight gain (Gartner et al. 1981) of cattle.

The higher WW, P-WG and P-ADG in humid and dry subhumid zones calves are attributed by favourable agroecological factors which have induced minimal postnatal stress. This could have resulted from the fact that these zones receive enough rainfall for plant or forage growth, and its soils have high level of iron and aluminium which are essential for optimum plant growth (Mohammed-Saleem 1995) resulting in cows producing more milk.
Table 8 Season of birth and sex of calves' interaction effects on pre-weaning calf performance (kg) of Nguni cattle in Limpopo province, South Africa

\begin{tabular}{llllll}
\hline Source & $N$ & BW & WW & P-ADG & P-WG \\
\hline Summer $\times$ females & 240 & $24.74^{\mathrm{a}} \pm 0.27$ & $110.58^{\mathrm{b}} \pm 1.18$ & $0.419^{\mathrm{a}} \pm 0.23$ & $85.85^{\mathrm{b}} \pm 1.21$ \\
Winter $\times$ females & 161 & $25.62^{\mathrm{a}} \pm 0.32$ & $128.20^{\mathrm{a}} \pm 1.42$ & $0.500^{\mathrm{a}} \pm 0.20$ & $102.58^{\mathrm{a}} \pm 1.45$ \\
Summer $\times$ males & 255 & $24.68^{\mathrm{a}} \pm 0.25$ & $128.16^{\mathrm{a}} \pm 1.13$ & $0.504^{\mathrm{a}} \pm 0.24$ & $103.48^{\mathrm{a}} \pm 1.16$ \\
Winter $\times$ males & 170 & $25.04^{\mathrm{a}} \pm 0.31$ & $106.66^{\mathrm{b}} \pm 1.36$ & $0.398^{\mathrm{a}} \pm 0.19$ & $81.61^{\mathrm{b}} \pm 1.39$ \\
\hline
\end{tabular}

${ }^{\mathrm{a}, \mathrm{b}}$ Values in the same column with different superscripts differ significantly $(P<0.05)$

$B W$ birth weight, $W W$ weaning weight, $P-A D G$ pre-weaning average daily gain, $P-W G$ pre-weaning gain 
The season of birth shows a significant effect on BW, PADG and P-WG of Nguni calves. Melaku et al. (2011) reported that season had an effect on BW of Fogera calves. However, contrary findings by Amsalu (2003), Getinet et al. (2009) and Addisu et al. (2010) reported non-significant effects of season on BW of calves of different breeds (Nguni, Bonsmara, Hereford and Brahman). Summer calves had higher WW than winter calves because they were calved in season where most of the rain is received which is ample for plant growth and therefore milk production by their dams. On contrary, Venter (1977) reported that Nguni winter calves had higher weaning weight.

Fairly constant trends in BW across the sex of calves indicate the ability of the Nguni dams to provide a neutral prenatal environment for calf growth irrespective of the sex of the calves. Similar results had been reported (Maarof and Arafat 1987; Wilson and Traole 1988); however, on the contrary, Melaku et al. (2011) reported that BW of Fogera calves is affected by the sex. Except BW, all other weights between sexes were significantly different where male calves tended to weigh heavier at weaning and have higher P-ADG and P-WG than heifer calves. The sexual dimorphism was evident in pre-weaning growth performance of Nguni calves in which male calves weighed heavier than females. Ebangi (2000) also described that male calves are heavier than heifer calves from birth to weaning and ascribed that these differences are due to differences in their endocrinological and physiological functions, together with increased selection for growth rate on male calves compared to heifer calves. Male calves develop more muscle and less fat than females in summer; fat rather than muscle is advantages in winter (Beebee and Rowe 2008), thus causes the male summer calves and winter calves outperforming the male winter calves and female summer calves.

The mean BW of Nguni calves obtained in the present study is similar to the South African Nguni Breeders Association estimated average BW in extensive system. Similar BW had been reported by Schoeman (1996) and du Plessis et al. (2006) who reported 27 and $26.5 \mathrm{~kg} \mathrm{BW}$ of Nguni calves. However, different results had been reported; Schoeman (1989), Scholtz et al. (2000) and Collin-Lusweti (2000) reported higher Nguni calves' BW of $29.1,36$ and $30.3 \mathrm{~kg}$, respectively. The mean WW of the present study is lower to reports by CollinLusweti 2000 (135 kg), Scholtz et al. (2000) (215 kg), du Plessis et al. (2006) (161 kg) and South African Nguni Breeders Association of $155 \mathrm{~kg}$ estimated WW but still acceptable in extensive grazing system. The P-ADG of this study is lower compared to results reported by Scholtz et al. (2000) (0.873 kg/day), Schoeman (1989) $(0.734 \mathrm{~kg} / \mathrm{day})$ and du Plessis et al. (2006) $(0.659 \mathrm{~kg} /$ day) in different regions of South Africa.

\section{Conclusion}

In conclusion, the study revealed that pre-weaning growth performance of Nguni cattle is dependent on agro-ecological zone factors. Nguni cattle should be bred to calve in summer season; given a favourable environment, summer calves will outperform winter calves at its optimum genetic potential. Genotype $\times$ environment mechanisms can play a major role in pre-weaning performance of Nguni cattle. The results of this study may indicate the presence of genotype $\times$ environment mechanisms, and this stimulated a literature study on the effect of genotype $\times$ environment mechanisms on animal production. It was concluded that acceptable levels of growth are achievable from Nguni cattle whilst grazing on natural pastures without nutritional supplements under the different agroecological zones of Limpopo province, South Africa.

Acknowledgments The authors wish to thank the Limpopo Nguni cattle breeders and their entire workforce in their farms for their invaluable assistance and data collection.

\section{Compliance with ethical standards}

Conflict of interest The authors declare that they have no conflict of interest.

Open Access This article is distributed under the terms of the Creative Commons Attribution 4.0 International License (http:// creativecommons.org/licenses/by/4.0/), which permits unrestricted use, distribution, and reproduction in any medium, provided you give appropriate credit to the original author(s) and the source, provide a link to the Creative Commons license, and indicate if changes were made.

\section{References}

ADDisU, B., MENGistie, T., ADEBABAY, K., GETINET, M., ASAMINEW, T., TEZERA, M., \& GEBEYEHU, G., 2010. Milk yield and calf growth performance of cattle under partial suckling system at Andassa Livestock Research Centre, North West Ethiopia. Livestock for Rural Development 22. Article \#136. From: http://www.Irrd.org/Irrd22/8/bite22136.htm (accessed 13 July 2016)

AMSALU, S., 2003. Growth performance of Boran cattle and their Friesian crosses in Ethiopia Pp235. Proceeding of 11th Annual conference of the Ethiopian Society Animal Production (ESAP). August 28-30, 2003. Addis Ababa, Ethiopia.

ARTHUR, P.F., RENAND, G., \& KRAUSS, D., 2001b. Genetic and phenotypic relationships among different measures of growth and feed efficiency in young Charolais bulls. Livestock Production Science 68, 131-139.

BEEBEE, T., ROWE, G., 2008. Introduction to molecular ecology. Second Edition, Oxford Press, London.

BOITSIME, B.D., 2006. Influence of agro-ecological region on selected anthropometrical measurements of Nguni cattle in South Africa. MSc Animal Science Dissertation. University of Pretoria, South Africa. 
BOTHMA, A. J. 1993. Comparison of the government Nguni studs in Venda. MSc Thesis, University of Pretoria, South Africa.

BOURDON, R. M., 2000. Understanding animal breeding. 2ened. Prentice Hall. New Jersey. Burfening. P. 102.

BURFENNING, P.J., KRESS, D.D., \& FRIEDRICH, R.L., 1982. Sire $\mathrm{x}$ region of U.S and herd interactions for calving ease and birth weight. Journal of Animal Science 55, 765

COLLIN-LUSWETI, E., 2000. Performance of Nguni, Afrikander and Bonsmara cattle under drought conditions in the North West Province of Southern Africa. South African Journal of Animal Science 30, 33.

CORREA, M.B., DIONELLO, B., \& CARDOSO, F.F., 2006. Estimation of genetic parameters and (co) variance components for pre-weaning productive traits in Devon cattle in Rio Grande do Sul. Brazilian Journal of Animal Science 35, 997 - 1004.

De WAAL, H.O., 1990. Animal production for native pasture (veld) in the Free State region. A perspective of grazing ruminants. South African Journal of Animal Science 20 (1), $1-8$.

DeNISE, S.K., \& RAY, D.E., 1987. Postweaning weights and gains of cattle raised under range and gain test environments. Journal of Animal Science 64, 969.

DIONISIO, A.C., 1989. Evaluation of growth and reproductive performance of Nguni and Afrikaner cattle in Chobela Research Station Mozambique. M.Sc thesis, Agricultural University of Norway, Norway.

DOOLEY, V., DINKEL, C., McPEAKE, C.A., \& LASLEY, E.L., 1982. A survey evaluation of South Dakota beef cattle production. Journal of Animal Science 55, 224.

Du PLESSIS, I., HOFFMAN, L.C., \& CALITZ, F.J., 2006. Influence of reproduction traits and pre-weaning growth rate on herd efficiency of different beef breed types in an arid sub-tropical environment. South African Journal of Animal Science 2006, 36 (2), 89-98.

DUARTE-ORTUNO, A., THORPE, W., \& TEWOLDE, A., 1988. Reproductive performance of purebred and crossbred beef cattle in the tropics of Mexico. Animal Production 47, $11-20$.

EBANGI, A.L., 2000. Genetic improvement of beef cattle in a tropical environment with special reference to the Gudali and Wakwa breed in Cameroon. Ph.D Thesis, University Orange Free State, South Africa.

ERAT, S., \& BUCHANAN, D.S., 2005. Milk production, calf performance, body weight and condition score of mature beef cows sired by high and low milk EPD Angus and Hereford bulls. Copyright 2005 Oklahoma Agricultural Experiment Station. http://www.ansi. okstate.edu/research/2005 rr/2005 rr/14/14.htm.

GARTNER, B.J.W., MURPHY, G.M., \& HOEYA, W.A., 1981. Effects of induced, subclinical phosphorus deficiency on feed intake and growth of beef heifers. The Journal of Agricultural Science 98 (1), $23-29$.

GETINET, M., WORKNEH, A., \& HEGDE, B.P., 2009. Growth and reproductive performance of Ogaden cattle at Haramaya University, Ethiopia. Ethiopian Journal of Animal Production 9 (1), $13-38$.

HOWDEN, S.M., McKEON, G.M., WALKER, L., CARTER, J.O., CONROY, J.P., DAY, K.A., HALL, W.B., ASH, A.J., \& GHANNOUM, O, 1999. Global change impacts on native pastures in south-east Queensland, Australia. Environmental Modelling and Software 14, $307-316$.

HUNTERS, R.A., \& BUCK, N., 1992. Nutrition and climatic limits of beef production in the tropics. In: Jarrige, R., \& Beranger, C., (Eds.) World Animal Science. C5. Beef Cattle Production. Elsevier Science Publisher, The Netherlands. pp. 379-387.

JONES, R.N., \& HENNESSY, K.J., 2000. Climate Change Impacts in the Hunter Valley: A Risk Assessment of Heat Stress Affecting Dairy Cattle. CSIRO Atmospheric Research, Aspendale, Victoria, Australia, pp 22-28.
LAWRENCE, T. L. J., \& FOWLER, V.R., 2002. Growth of farm Animals. CABI Publishing, United Kingdom. Pp. 1-6, 277-317.

LEIGHTON, E.A., WILHAM, R.L., \& BERGER, P.J., 1982. Factors influencing weaning weights in Hereford cattle and adjustment factors to correct records of these effects. Journal of Animal Science 54, 957.

LETHOLU, L.L., 1983. Review of Tswana breed cattle. Proceedings of the expert committee on animal genetic resources in Africa, Bulawayo, Zimbabwe.

MAAROF, M.N., \& ARAFAT, I.A. (1987). Some factors affecting birth and weaning weight in Friesian cattle. Animal Breeding Abstracts $55,596$.

MACIEL, S., AMIMO, J., MARTINS, M., OKEYO, A.M., SCHOLTZ, M.M., \& NESER, F. W. C., 2013. Feedlot performance of the Nguni ecotypes in southern Mozambique. Livestock Research for Rural Development 25 (6).

MEKONNEN, H.M. \& GOSHU, M. (1996) Reproductive performance of zebu, Friesian and Friesian-Zebu crosses. Tropical Agriculture 72 (3).

MELAKU, M., ZELEKE, M., GETINET, M., \& MENGISTIE, T., 2011. Pre-weaning growth performances of Fogera calves at Metekel cattle improvement and multiplication ranch, North West Ethiopia. Livestock Research for Rural Development 23 (9). Accessed September, 23, 2012 from http://www.lrrd.org/lrrd23/9/mela23182. htm.

MOHAMMED-SALEEM, M.A., 1995. Mixed farming systems in subSaharan Africa. Livestock development strategies for low income countries. Proceedings of the joint FAO/ILRI roundtable on livestock development strategies for low income countries, ILRI, Addis Ababa, Ethiopia.

MOYO, S., 1996. The productivity of indigenous and exotic beef breeds and their crosses at Matopos, Zimbabwe. PhD (Agric) Thesis, University of Pretoria, South Africa.

OWENS F.N., DUBESKI P., \& HANSON C. F., 1993. Factors that alter the growth and development of ruminants. Journal of Animal Science $71,3138-3150$.

RONCHIETTO, P.C., 1993. The effect of agro-ecological regions on beef production in Natal. M.Sc (Agric) Thesis, University of Pretoria, South Africa.

SAS INSTITUTE INC, 2013. SAS user guide: Statistical Analysis Software, Inc. Carry, NC, USA

SCHOEMAN, S.J., 1989. Recent research into the production potential of indigenous cattle with special reference to the Sanga. South African Journal of Animal Science 19, 206 - 209.

SCHOEMAN, S.J., 1996. Characterization of beef cattle breeds by virtue of their performance in the National Beef Performance and Progeny Testing Scheme. South African Journal of Animal Science 26, 15 19.

SCHOLTZ, M.M., 2000. Selection possibilities of hardy beef breeds in Africa: the Nguni example. In: Proceedings of the $3 r d$ World Congress. Sheep and cattle Breeding, Paris, France.

SCHULZE, R.E., 1997. South African Atlas of Agrohydrology and Climatology. Water Research Commission, Pretoria Report TT82/ 96.

SZABO, F., SZABO, E., \& BENE, S., 2012. Statistic and genetic parameters of 205-day weaning weight of beef calves. Archives of Animal Breeding 55, $552-561$.

TREDEEN, H.T., WEIS, G.M., RAHNEFELD, G.W., LAWSON, J.E., \& NEWMAN, J.A., 1982. Environmental and genetic effects on pre-weaning performance of calves from first cross cows. II Growth traits. Canadian Journal of Animal Science 62, 51.

VENTER, H.A.W., 1977. Die invloed van voorspeense groei by sekere vleis-, dubbeldoel- en kruisrasse in die Noord-Transvaalse Soetbosveld. DSc (Agric) Thesis, University of Pretoria, South Africa. 
WILSON, R.T., \& TRAOLE, A., 1988. Livestock production in central Mali: Reproductive performance and reproductive wastage in ruminant in the agro-pastoral system. Theriogenology. 29, 931 944.

WOLLNY, C.B.A., 1995. Conserving the biodiversity of Southern African livestock resources. Keynote address presented at the annual symposium of developing areas branch of the South African Society of Animal Science (SASAS), Loskop dam, Groblersdal, South Africa.

ZINDOVE, T.J., 2014. Relationship between linear type traits and fertility in Nguni cows. PhD Animal Science Thesis, University of KwaZulu-Natal, Durban, South Africa. 